trations in benign conditions is a disadvantage. However, the failure to detect two out of three early carcinomas of the cervix precludes its use as a screening test in its present form.

\section{Summary}

Experience with assays of 6-phosphogluconate dehydrogenase in vaginal fluid as a screen test for cervical carcinoma in parallel with cervical cytology is described. Among the 190 cases studied, three cases of carcinoma-in-situ were found. Two of the three carcinomas-in-situ did not have raised enzyme levels. Thirty-five patients had raised enzyme levels without carcinoma. The causes of high enzyme concentration in the absence of carcinoma and low concentration in carcinoma-in-situ as distinct from frank carcinoma are discussed.

We wish to acknowledge the funds presented to us by the Common Council of the City of London and the British Empire Cancer Campaign. This work was carried out while one of us (G. G. M.) held the Gillson Scholarship in Pathology of the Worshipful Society of Apothecaries of London. We are grateful to Mr. J. Beattie and the surgeons of the gynaecology department for access to patients under their care, and to Professor W. G. Spector and Dr. A. B. Anderson for advice and encouragement.

REFERENCES

Bonham, D. G. (1964). Triangle, 6, 157.

- and Gibbs, D. F. (1962). Brit. med. 7., 2, 823.

Chayen, J. (1961). Ann. Rep. roy. Coll. Surg. Engl., 68, 75.

de Duve, C., Pressman, B. C., Gianetto, R., Wattiaux, R., and AppelDuve, C., Pressman, B. C., Gianetto, $R$,

Fishman, W. H., Kasdon, S. C., and Homburger, F. (1950). 9. Amer. med. Ass., 143, 350 .

Glock, G. E., and McLean, P. (1953). Biochem. 7., 55, 400.

Hatzimichael, A. (1962). Amer. Ұ. Obstet. Gynec., 84, 94.

Kotnis, L. B., Narurkar, M. V., and Sahasrabudhe, M. E. (1962a). Brit. f. Cancer, 16, 541 .

- (1962b). Ibid., 16, 550.

Lawson, J. G. (1959). 尹. Obstet. Gynaec. Brit. Emp., 66, 946.

Odell, L. D., and Burt, J. C. (1950). F. Amer. med. Ass., 142, 226.

Papanicolaou, G. N. (1954). Atlas of Exfoliative Cytology. Oxford, London.

Scott, D. B. M., Morris, A. L., Reiskin, A. B., and Pakoskey, A. M (1962). Cancer Res., 22, 857.

Smith, B., and Rubinstein, L. J. (1962). F. Path. Bact., 83, 572.

Walker, P. G. (1952). Biochem. F., 51, 223.

and Levvy, G. A. (1952). İbid., 51, 20.

Wa (1953). Ibid., 54, 56.

Watkins, D. K., and Lawson, J. G. (1963). Clin. Chim. Acta, 8, 646.

\title{
Control of Tuberculosis in Pakistani Immigrants
}

\author{
W. EDGAR,* M.B., CH.B., D.P.H., D.C.H.
}

There has been a small community of Pakistanis in Bradford for some years, but towards the end of 1960, possibly owing to the impending restrictions on entry into this country, the number rose at an alarming rate. At the 1961 Census there were 4,969 Indians and Pakistanis, and by the end of 1963 it is estimated that the number of coloured immigrants had increased to 12,688 , of whom $10,863(85.6 \%)$ were Pakistanis.

The reason for their presence here is that the local textile trade provides many suitable jobs for them. The largest proportion are employed in the mills, particularly in simple unskilled jobs like woolcombing and the ancillary textile processes, where the atmosphere tends to be hot and humid. In many mills the night shift is composed almost entirely of Pakistanis. Apart from administrative and clerical staff, $20 \%$ of the male textile force are coloured. Others are engaged in foundry work, in public transport, and in unskilled engineering. The great majority are men aged 20 to 40 whose length of stay is limited to a few years, during which time they support their wives and families by sending money home to Pakistan. Those who have set up in business along with those who have brought their families with them are likely to remain permanently, and although the number is not great it is steadily increasing.

The number of newly arrived Commonwealth immigrants who registered at the Bradford Employment Exchange between 1959 and 1963 is shown in Table I. These are almost entirely from Pakistan. Undoubtedly others, of whom the Exchange would have no record, obtained jobs within a few days of arrival, although the number is probably small. Those who entered the country with a voucher for employment with a specific employer would proceed direct to their job, and would not register at the Employment Exchange. Approximately 83 such vouchers were issued during 1963 in respect of Pakistanis and Indians coming to employment in Bradford. These figures * Formerly Deputy Medical Officer of Health and Deputy Principal
School Medical Officer, City of Bradford. relate to new arrivals in the United Kingdom and do not include those moving into Bradford from other parts of the country.

I am indebted to Miss M. Gething, Manager of the Employment Exchange, for the following account, on 20 December 1963, of the effect of the Commonwealth Immigrants Act.

"The main object of the Commonwealth Immigrants Act 1962 is to control immigration of Commonwealth citizens to the United Kingdom. The basic feature of this control is that all Commonwealth citizens to whom the Act applies and who wish to enter Great Britain for the purpose of taking or seeking employment must obtain a voucher from the Ministry of Labour. These vouchers are issued to three categories of Commonwealth citizens: (a) those to whom an employer in Great Britain is prepared to make a genuine offer of employment ; $(b)$ those with certain special qualifications or skill but with no job to come to; and $(c)$ those not included in category $a$ or $b$.

"Vouchers are issued without restriction to persons coming within categories $a$ and $b$, but the number issued in category $c$ is controlled. The Government's policy is to control the flow of immigrants into the country so that they do not come here faster than they can be absorbed into our national life.

TABLE I.-New Arrivals of Commonwealth Immigrants Attending the

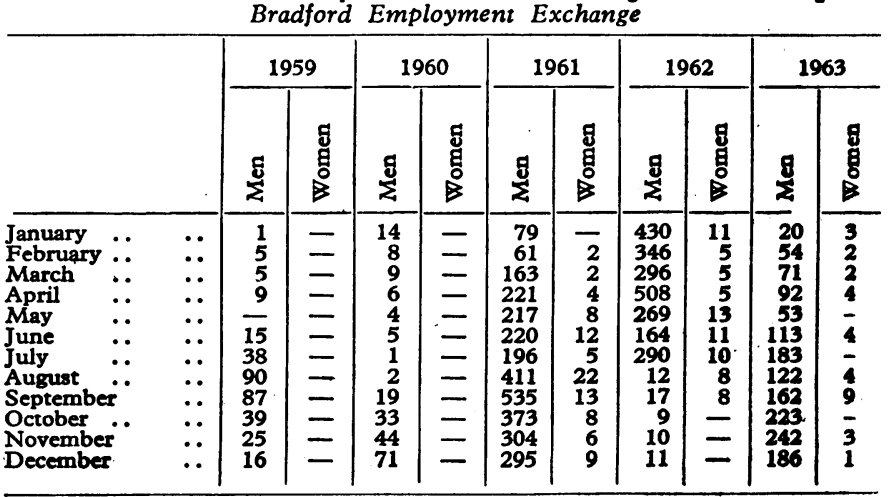


“Applications for category $c$ vouchers are made by the Commonwealth citizens direct to the Headquarters of the Ministry of Labour or through the United Kingdom representative in the country concerned. They are issued on the basis of 'first come, first served,' except that applicants who can prove they have served in the U.K. Naval, Military, or Air Forces since the end of the Second World War are granted priority in the issue of vouchers.

"Almost all of the newly arrived immigrants in Bradford enter this country on category $c$ vouchers. The control in the number of these vouchers means that there is a delay of some months before vouchers can be issued, and this is probably one of the reasons why the number of new arrivals was so small in the second half of 1962. By the beginning of 1963 the method of obtaining vouchers would have become better known in the villages in Pakistan and India and the numbers applying for vouchers could be expected to increase.

"In 1961 the number of new arrivals from Pakistan and India totalled 2,802 ; from January to July 1962 there were 2,202 and for 1963 only 1,501. Had there been no control it is probable that the rate for the second half of 1962 would have been similar to that of the earlier part of the year and the total could well have exceeded 4,500."

\section{Incidence of Tuberculosis}

Pakistanis with tuberculosis were first seen at Bradford Chest Clinic in 1954. Since then the number has increased at an alarming rate and a high incidence of tuberculosis has been discovered. Table II shows that since 1961 more cases of pulmonary tuberculosis have been notified among the Pakistani population than from the rest of the male population in the city. Although this problem has been under constant scrutiny since 1955, and despite determined efforts to keep the increasing Pakistani population under the closest radiological supervision, the incidence of this infection among the immigrants continues at a high level.

TABLB II.-Number of Cases Notified Suffering from Tuberculosis,

\begin{tabular}{c|c|c|c|c|c|c|c}
\hline & \multicolumn{3}{c|}{ Non-Asians } & \multicolumn{3}{|c|}{ Asians* } & Total \\
\cline { 2 - 6 } & Men & Women & Children & Men & Women & Children & \\
\hline 1954 & 174 & 113 & 40 & 12 & - & - & 339 \\
1955 & 177 & 101 & 31 & 20 & - & - & 329 \\
1956 & 150 & 120 & 31 & 21 & - & - & 322 \\
1957 & 159 & 110 & 31 & 26 & 3 & 1 & 330 \\
1958 & 147 & 92 & 20 & 67 & 4 & 7 & 330 \\
1959 & 120 & 59 & 16 & 83 & 2 & 5 & 285 \\
1960 & 118 & 66 & 17 & 61 & 3 & 2 & 267 \\
1961 & 110 & 56 & 20 & 124 & 2 & 1 & 213 \\
1962 & 83 & 47 & 9 & 209 & 6 & 4 & 358 \\
1963 & 94 & 52 & 12 & 198 & 9 & 5 & 370 \\
\hline
\end{tabular}

- Almost exclusively from Pakistan.

\section{Control Measures}

This paper, which excludes the contact tracing of index cases, outlines the measures adopted during the past two years to deal with the problem: (1) a more realistic approach to overcrowding among Pakistanis ; (2) a more selective use of mass radiography ; and (3) a scheme for skin-testing Pakistanis employed in the textile mills.

\section{Abatement of Overcrowding}

This influx of Pakistanis has been on a purely voluntary basis, immigrants being accommodated by the relatives and friends mainly instrumental in bringing them to Bradford. The arrival of 40-50 immigrants each week in a city already short of housing accommodation, where the authority, while building as many dwellings as it can, has simultaneously been proceeding with a vast programme of slum clearance, has created new problems of overcrowding.

Had very strict steps been taken initially, much hardship would have resulted, because alternative accommodation was just not available and the surplus occupants would have been driven into other dwellings, merely perpetuating the problem.

Owing to the close association between overcrowding and the spread of tuberculosis, considerable effort has been directed during the past two years to this problem of multiple occupation. Some 1,052 dwellings occupied by Pakistanis have been inspected and 624 found to be overcrowded. In general, four out of five of these were found upon revisiting to have remedied the position. So far there have been only two prosecutions. While the accommodation of Pakistani families presents no particular difficulty, the problem of housing the "single" men, who constitute by far the greatest number, is considerable. The provision of special hostels has been discussed, but has been opposed on grounds of segregation and because there could be no certainty that the men would take advantage of such accommodation if provided.

During 1963 the City Council approved the conversion of old-type Victorian houses into houses to be let in lodgings in an attempt to provide temporary accommodation for those rendered homeless as a result of the abatement of overcrowding. Schemes have been prepared to divide these houses into rooms let as lodgings, each room being provided with a means of heating and cooking, a sink with hot and cold water, and a bathroom and toilet for each two lodgings.

\section{Mass Miniature Radiography}

Since 1956, individual surveys have been held and every possible means used to encourage Pakistanis to the unit-by advertising, public talks, showing slides in Urdu to Pakistani cinema audiences, household canvassing, and street surveys with the mobile unit in the Pakistani districts of the city-all without success.

The mobile unit has visited textile mills every two or three years with somewhat better results owing to the wholehearted co-operation of the managements and the late night sessions arranged by the unit to facilitate the attendance of night-shift workers. In this way 62 persons with tuberculosis have been found over the past two years, 42 of whom were Pakistanis.

Owing to a temporary recession in trade during 1962, some 1,600 Pakistanis were attending the Employment Exchange. A visit by the mobile unit was discussed with the manager and permission subsequently received from the Ministry of Labour.

As some four months elapsed from the time of the initial discussions to the actual visit the number of Pakistanis attending the Exchange had fallen. Of 1,008 persons passing through the unit, 850 were Pakistanis, amongst whom 26 new cases of tuberculosis were found-an incidence of $3.06 \%$. A return visit was paid to the Employment Exchange in November 1963, and on this occasion 396 Pakistanis were $x$-rayed and 12 new cases of tuberculosis found-an incidence of $3.03 \%$.

The results of the mass miniature radiography surveys since 1956 are shown in Table III.

The overall incidence of $1.8 \%$ is 13 times the incidence $(0.14 \%)$ in the local white population. These figures are in respect of surveys mounted specially for Pakistanis and do not include those attending as contacts or attending general surveys. Numbers in the latter group are at least equal to the total shown, with an incidence of approximately $1 \%$.

Approximately 10,000 Pakistanis have been examined by the unit since 1956, with a total of 150 cases of active tuberculosis

TABLE III.-M.M.R. Unit Special Surveys for Pakistanis

\begin{tabular}{|c|c|c|c|c|c|}
\hline & & & & No. Examined & $\begin{array}{c}\text { Cases of } \\
\text { Active Tuberculosis }\end{array}$ \\
\hline $\begin{array}{l}1956 \\
1959 \\
1960 \\
1961 \\
1962 \\
1963\end{array}$ & $\begin{array}{l}\because \\
\because \\
\because\end{array}$ & $\begin{array}{l}\ldots \\
\because \\
\because \\
\ldots\end{array}$ & $\begin{array}{l}\because \\
\because \\
\because \\
\because\end{array}$ & $\begin{array}{r}610 \\
270 \\
229 \\
437 \\
2,414 \\
1,424\end{array}$ & $\begin{aligned} 5 & (0.8 \%) \\
6 & (2.2 \%) \\
9 & (3.9 \%) \\
2 & (0.4 \%) \\
23 & (0.9 \%) \\
51 & (3.6 \%)\end{aligned}$ \\
\hline
\end{tabular}


revealed. Approximately 110 of these were minimal primary lesions ; the remainder showed progressive post-primary disease.

\section{Tuberculin-testing}

Towards the end of 1962 the Wool Industry Bureau of Statistics undertook a survey of textile firms in Yorkshire, and, with their kind permission and through the Chamber of Commerce, valuable information was received regarding the number of Pakistanis employed by the individual textile firms in the city. This survey also demonstrated the large number employed in the small towns adjoining, although many undoubtedly live in Bradford. Out of 6,379 Pakistanis employed in the textile trade in Bradford and its immediate environs, only 3,171 were working in the city. Of these, 2,632 were working in 31 mills employing 25 or more Pakistanis.

As the scheme for skin-testing had already received the approval of the Chamber of Commerce, a letter incorporating this support was sent to the managements of these mills. This drew attention to the high incidence of tuberculosis among Pakistanis compared with the local population and offered a skin test ${ }^{1}$ to all members of their staff, in order that those found to be negative and susceptible could be given the protection of B.C.G. vaccination and those found to have a strong reaction to the skin test could have a chest $\boldsymbol{x}$-ray examination.

Of the 31 firms approached, all but one accepted the offer. As most of the immigrants were employed on night shift this involved visits to the mills at all hours. Approval was also received from the Ministry of Labour for a similar scheme to be offered to all those attending the Employment Exchange.

The difficulty of explaining such a scheme was overcome by the use of a tape recording of an appropriate message in Urdu and Bengali.

The results are summarized in Table IV and V.

TABLE IV.-Employed Pakistanis : Tuberculin Reactions

\begin{tabular}{|c|c|c|c|c|c|c|}
\hline \multirow{2}{*}{$\begin{array}{c}\text { Total } \\
\text { Tested }\end{array}$} & \multicolumn{4}{|c|}{ Degree of Positivity } & \multirow{2}{*}{ Neg. } & \multirow{2}{*}{ Abs. } \\
\hline & 1 & 2 & 3 & 4 & & \\
\hline 2,446 & $\begin{array}{c}712 \\
(30 \cdot 4 \%)\end{array}$ & $\begin{array}{c}659 \\
(28 \cdot 1 \%)\end{array}$ & $\begin{array}{c}434 \\
(18 \cdot 6 \%)\end{array}$ & $\begin{array}{c}223 \\
(9 \cdot 5 \%)\end{array}$ & $\begin{array}{c}322 \\
(13 \cdot 4 \%)\end{array}$ & 96 \\
\hline
\end{tabular}

TABLE V.-Pakistanis Attending Employment Exchange: Tuberculin Reactions

\begin{tabular}{c|c|c|c|c|c|c}
\hline \multirow{2}{*}{$\begin{array}{c}\text { Total } \\
\text { Tested }\end{array}$} & \multicolumn{4}{|c|}{ Degree of Positivity } & Neg. & Abs. \\
\cline { 2 - 5 } & 1 & 2 & 3 & 4 & & \\
\hline 682 & 131 & 115 & 141 & 71 & $51(10 \%)$ & 173 \\
\hline
\end{tabular}

The incidence of negative reactors $(13.4 \%$ ) is surprisingly low (varying in individual firms from $1 \%$ to $34 \%$ ), and it was possible to offer B.C.G. vaccination to only 322 of those tested. The incidence of positive reactors $(86.6 \%)$ indicates fairly widespread infection among this section of the population.

On account of the high incidence of strongly positive reactors (9.5\%), arrangements were made for 223 showing fourth-degree reactions to attend for chest $x$-ray examination. Of these, 206 attended and 21 unknown cases of tuberculosis were foundthat is, $10.2 \%$ of apparently healthy working Pakistanis in this selected group.

Of the 682 tested at the Employment Exchange only 509 returned the following week to have the skin test read. Of

1 The Heaf M.P. test was used, the results being read one week later. Positive reactions were recorded as follows: 1st degree, discrete palpable induration of 4 or more of the puncture points; 2nd degree, coalescence of individual points to form continuous ring of induration; 3rd degree, solid weal of induration over the whole area ; 4th degree, vesiculation or crusting over each puncture or even central necrosis. Puncture scars with no true induration were recorded as negative reactions. these, $51(10 \%)$ were negative and received B.C.G. vaccination. During the second week, when the skin tests were being read, the M.R.U. simultaneously examined 850 Pakistanis, of whom 26 were found to be suffering from pulmonary tuberculosis. Of these, 22 had received a skin test, $9(6.4 \%)$ showing thirddegree and $13(18.3 \%)$ fourth-degree reactions.

An analysis of 459 Pakistanis attending the Employment Exchange, correlating the reaction to the skin test with the duration of stay in this country, is shown in Table VI. As the numbers, particularly in the " under 6 months" group, are small, no conclusions can be drawn. Nevertheless, the figures tend to support a negative-reaction rate of approximately $10 \%$ amongst all groups except the most recent arrivals.

TABLE VI.-Tuberculin Reaction Related to Length of Stay in United Kingdom

\begin{tabular}{|c|c|c|c|c|}
\hline & & Positive & Negative & Total \\
\hline \multirow[t]{2}{*}{$\begin{array}{l}\text { Under } 6 \text { months } \\
6-12 \text { months } \\
1-2 \text { years } \\
2-5 \text { years }\end{array}$} & $\begin{array}{l}\ldots \\
\cdots \\
\cdots\end{array}$ & $\begin{array}{r}9 \\
147 \\
146 \\
102\end{array}$ & $\begin{array}{r}5(36 \%) \\
18(10 \%) \\
23(13 \%) \\
9(9 \%)\end{array}$ & $\begin{array}{r}14 \\
165 \\
169 \\
111\end{array}$ \\
\hline & & 404 & 55 & 459 \\
\hline
\end{tabular}

\section{Clinical Details}

An analysis of the 43 cases found in association with the scheme for skin-testing (21 in employment, 22 attending Employment Exchange) gave the following results :

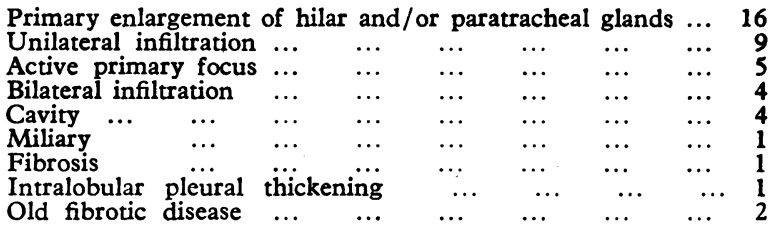

The average age of those showing primary glandular enlargement was 25.4 years and those showing active primary focus 31 years.

\section{Discussion}

The arrival of a large number of immigrants into a previously stable community is an occurrence which is not without risk both to the immigrants and to the local population. When the immigrant population is composed largely of "single" males who do not speak the local language, whose customs differ widely from those of the country of temporary residence, and whose susceptibility to disease is aggravated by their inadequate diet and the overcrowded circumstances in which they have been obliged to live, the control of any health hazard is rendered more difficult. The introduction of smallpox into Bradford and the measures used to control the resulting outbreak have already been described (Douglas and Edgar, 1962; Edgar, 1962). This paper outlines the problem presented by the high incidence of tuberculosis which has been found among Pakistanis in Bradford and the measures adopted to deal with that problem.

The incidence of tuberculosis in India and Pakistan is much higher than in this country. The Indian Council of Medical Research (1959) revealed a tuberculosis morbidity rate of 250 per 10,000. Islam and Islam (1962) state that the incidence in Pakistan does not differ significantly from this figure.

A high incidence has also been demonstrated amongst Asian immigrants to this country (Springett et al., 1958 ; Roe, 1959 ; Stevenson, 1962; Aspin, 1962; Springett, 1964). The incidence among Pakistanis appears to be appreciably higher than in Indian immigrants. Stevenson (1962) estimated that tuberculosis in Pakistanis in Bradford was 30 times higher than in the local population, and a similar high incidence has been found by Springett (1964). 
Immigrants arriving without medical check from an area with a high incidence of tuberculosis include a number of cases which will become manifest at some time after their arrival. Stevenson (1962) was of the opinion that $40-50 \%$ of Pakistanis found to have tuberculous infection had abnormal $x$-ray pictures at the time of immigration. These undiagnosed cases are responsible for spread of the disease among their fellow countrymen and should be detected before arrival in this country.

The tuberculous immigrant is, however, only one facet of the total problem. A high proportion of Pakistani immigrants have been found to be tuberculin-positive. Among those showing a fourth-degree reaction to the Heaf test, an incidence of $10.2 \%$ active previously undiagnosed tuberculosis has been found and a somewhat lower incidence in those showing a third-degree reaction. The majority of the cases detected in this group present varying manifestations of primary infection, and, although not infectious at the time of detection, could and do rapidly develop acute florid tuberculosis with subsequent cavitation. It must be appreciated that this is an index of the problem of "latent tuberculosis" in the immigrant community, is in addition to that normally seen at the chest clinic, and presents a considerable challenge to those concerned with this problem.

A further aspect of the problem is the susceptible immigrant. The presence of tuberculin-negative reactors (Roe, 1959; Corbett, 1961) is confirmed in this survey, which shows an overall incidence of $13 \%$, although in four of the mills visited this exceeded $25 \%$.

The Heaf test, which is used routinely in the chest clinic, was chosen on account of ease in screening the large numbers involved. It is possible that some of the 712 first-degreepositive reactors included a number who would have proved Mantoux-negative to 1 T.U., although a significant difference would not be expected.

The problem, therefore, is not only that of the tuberculous Pakistani arriving in this country but also that of the susceptible immigrant and the large group of positive reactors, among whom a considerable number of early undiagnosed cases of tuberculosis have been found.

This is not a simple problem, nor is the abatement of overcrowding the simple remedy. The vast majority of Pakistani immigrants are unaccompanied men who work a five-day week and have long hours of leisure. They often crowd together to pass the time of day, since inadequate social facilities exist. This is aggravated in cold weather, when they crowd in large numbers into rooms often lacking in ventilation. Further, the hot humid conditions under which many work and the doubtful adequacy of the diet of many, despite every facility for good meals being available in the mills, underline the fact that abatement of overcrowding, which has now been achieved in Bradford, is by no means as powerful a weapon in dealing with this problem as might be supposed.

The most fruitful source of case-finding in the past has been referrals from general practitioners and hospitals and the subsequent tracing of contacts, amongst whom Stevenson (1962) found an incidence of 40 per 1,000. During the past two years the referrals from the mass radiography unit have increased appreciably as a result of the measures described. Out of 10,000 Pakistanis passing through the mass radiography unit to date approximately 150 were found to have active tuberculosis, the majority of these $(73.3 \%)$ having primary infections. As the period of residence in this country is seldom less than six months before the disease is diagnosed it is probable that many of these infections were acquired in this country.
The essence of control is early detection before cases become infectious. The most satisfactory method is based upon chest radiography before or upon entry into the country-a system practised with success by other countries.

The only "safeguard" existing at present is contained in the Commonwealth Immigrants Act, which empowers the immigration officer, on the advice of a medical inspector, to refuse admission to an immigrant if this is thought undesirable for medical reasons. This measure could only hope to deal with cases so advanced that clinical diagnosis is beyond doubt. Attempts to handle the problem at its source by obtaining notification of immigrants arriving in Bradford or, failing this, the names of those attending the Employment Exchange have not been successful, although a recent approach to the Ministry of Labour to hold regular skin-testing sessions at the Employment Exchange has been approved. A further possible measure which is under consideration is the requirement of a satisfactory chest $x$-ray examination before immigrants begin employment.

While the Commonwealth. Immigrants Act temporarily lowered the rising tide of immigrants from Pakistan and provided breathing-space in which some of the problems could be reviewed and tackled, it would appear that category $c$ is a ready means of access to this country. It is a disturbing thought that, in spite of the efforts made during the past two years, a further 1,124 Pakistanis arrived in Bradford during the second half of 1963. If immigration continues at this rate the problem will be almost insoluble.

There is no evidence of the problem abating, and while the steps undertaken have undoubtedly had some measure of success it must be acknowledged that this has been a laborious and time-consuming task, and in view of the continued arrival of immigrants without medical check a complete solution to the problem cannot be provided by even the most extensive schemes after entry into this country. Only by some central form of control is there any hope of relief from the enormous burden placed on those responsible for the control of tuberculosis in areas where large numbers of Pakistanis have settled.

\section{Summary}

A high incidence of tuberculosis among Pakistanis in Bradford has been confirmed by the present survey. To supplement the normal contact tracing of index cases, a more selective use of mass radiography has raised the "pick up " rate among Pakistanis from 1.5 per thousand to $3.26 \%$ in selected groups. A comprehensive tuberculin survey of 2,246 Pakistanis in the textile trade has been a valuable aid in raising this figure to $10.2 \%$ among fourth-degree reactors and in detecting susceptible immigrants, who have been offered B.C.G. vaccination. Measures adopted to deal with overcrowding of Pakistanis in houses in multiple occupation and the limitation of these as a means of influencing the incidence of tuberculosis are discussed.

\section{REFERENCES}

Aspin, J. (1962). Brit. med. 7., 1, 1386.

Corbett, J. T. (1961). 7. Coll.' gen. Practit., 4, 332

Douglas, J., and Edgar, W. (1962). Brit. med. $f_{\text {., }} 1,612$.

Edgar, W. (1962). "The Control of the Bradford Outbreak." (Paper presented at a meeting of the Royal Society of Health, London,
and July, 1962.)

Indian Council of Medical Research (1959). Tuberculosis in India: A sample survey, 1955-58, New Delhi. (Special Report Series, No. 34.) Islam, N., and Islam, N. (1962). Brit. med. F., 2, 552

Roe, J. 'I. N. (1954). Tubercle (Lond.), 40, 387.

Springett, V. H. (1964). Lancet, 1, 1091.

(1958). Brit. 7. prer soc. $M:$. . 12,135

Stevenson, D. K. (1962). Brit. med. F., 1, 1382. 